\title{
Unusual case of hyperpigmentation secondary to irinotecan
}

\author{
Laura Aisling Nestor, ${ }^{1}$ Stephen Flint, ${ }^{2}$ Sheila Galvin ${ }^{3}$
}

${ }^{1}$ Department of Dermatology, Adelaide and Meath Hospital, Tallaght, Ireland

${ }^{2}$ Department of Oral Medicine and Dentistry, Dublin Dental School and Hospital, Dublin, Ireland

${ }^{3}$ Department of Oral Medicine, Dublin Dental School and Hospital, Dublin, Ireland

\section{Correspondence to Dr Laura Aisling Nestor, lauranestor32@gmail.com}

Accepted 18 October 2016

\section{DESCRIPTION}

A 62-year-old Caucasian woman was referred to dermatology by oral medicine regarding intra and extraoral hyperpigmentation which had developed gradually over the past year. Her only significant medical history was stage 4 colorectal carcinoma diagnosed 8 years previously. It was initially surgically managed with adjuvant chemo and radiotherapy, however hyperpigmentation had since recurred and was now being treated with irinotecan (topoisomerase 1 inhibitor) and cetuximab (an epidermal growth factor receptor inhibitor) for the past 1 year. She had no family history of oral or cutaneous pigmentation disorders.

On examination she was normotensive with no postural drop. Cutaneous examination revealed mild hyperpigmentation of the dorsum of her hands and fingernails bilaterally (figure 1). There were also pigmented macules on her forehead, but no pigmentation of the palmar creases. Intraoral examination showed multiple brown pigmented macules on the dorsum of the tongue and hard palate (figures 2-4). Although the pattern of hyperpigmentation was diffuse, the timeline and absence

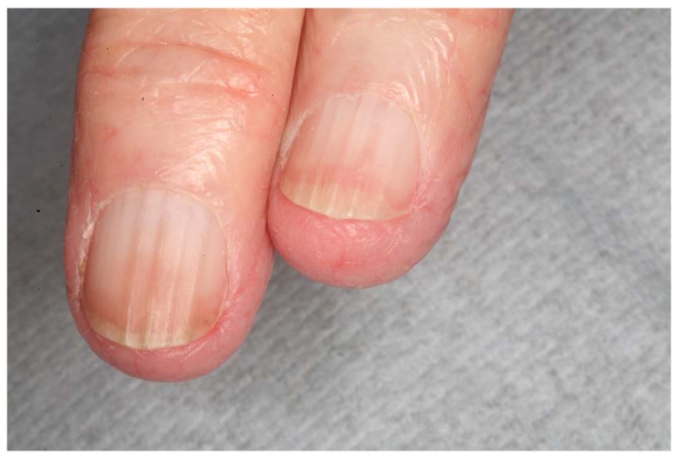

Figure 1 Hyperpigmentation of the distal fingernails.

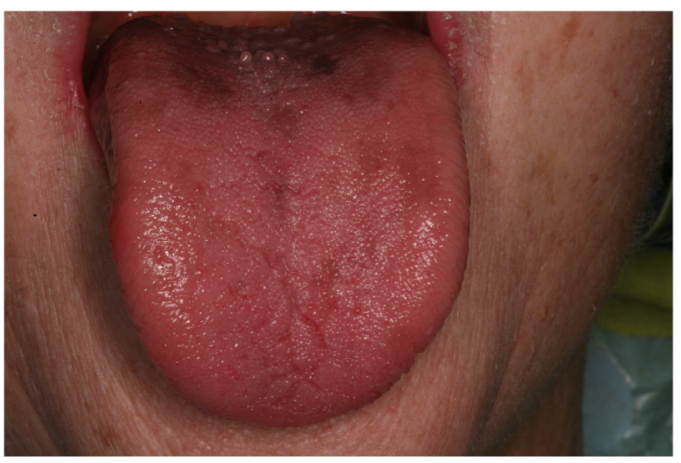

Figure 2 Hyperpigmentation involving posterior tongue. of other features enabled a diagnosis of exogenous oral and cutaneous hyperpigmentation secondary to irinotecan to be made.

Chemotherapy-related skin toxicity is a common presentation to dermatology, the most common side effects including mucositis and alopecia. ${ }^{1}$ Oral hyperpigmentation has a wide differential diagnosis. Common endogenous causes include labial melanotic macules, postinflammatory hypermelanosis and melanoacanthosis. ${ }^{2}$ Endocrine causes include Addison's disease, Nelson syndrome and McCune-Albright syndrome. ${ }^{2}$ Genetic causes such as Laugier-Hunziker syndrome and Peutz-Jeghers syndrome must also be considered, both inherited in an autosomal dominant manner. Mucosal hyperpigmentation is recognised with the use of antimetabolites, anthracyclines, alkylating agents, mitotic inhibitors and tyrosine kinase inhibitors. Doxorubicin, cyclophosphamide and hydroxyurea all cause pigmentation of the nail bed, a phenomenon known as chromonychia. The exact mechanism is unknown, however, it has been suggested that melanocyte-stimulating hormones may be boosted by certain chemotherapy agents like doxorubicin. ${ }^{3}$

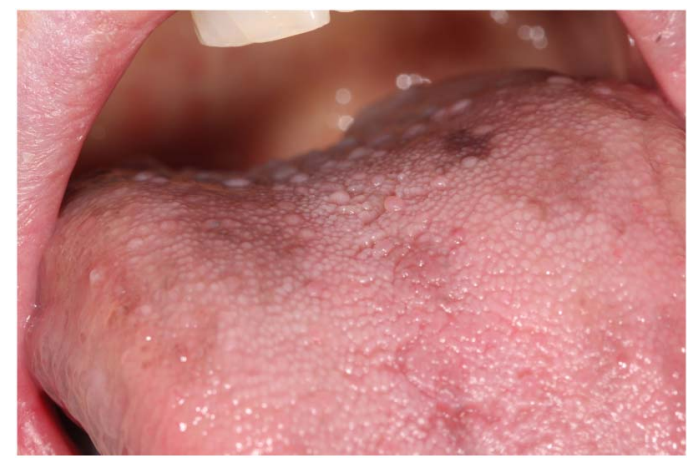

Figure 3 Hyperpigmentation involving posterior tongue.

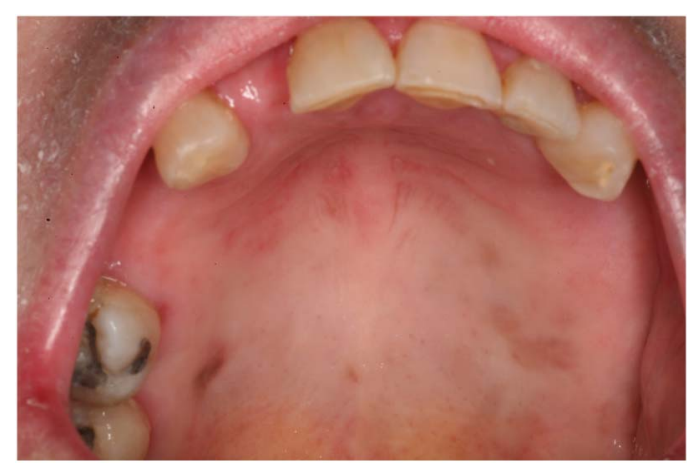

Figure 4 Hyperpigmentation involving the hard palate. 
Overall, the differential diagnosis of oral and acral hyperpigmentation is extensive and careful history and cutaneous examination should further help delineate the cause.

\section{Learning points}

- The importance of knowledge and recognition of the oral and cutaneous adverse events in patients receiving chemotherapeutics.

- It highlights above all the importance of multidisciplinary management of patients receiving chemotherapy. The importance of knowledge of the causes of mucosal and acral hyperpigmentation.
Contributors SG, SF and LAN participated in patient care. LAN contributed by writing the manuscript. SG revised the manuscript.

Competing interests None declared.

Patient consent Obtained.

Provenance and peer review Not commissioned; externally peer reviewed.

\section{REFERENCES}

1 Gill J, Dominguez A. Cutaneous manifestations of chemotherapeutic drugs. Curr Derm Rep 2016:5:58-69.

2 Sreeja C, Ramakrishnan K, Vijayalakshmi D, et al. Oral pigmentation: a review. J Pharm Bioallied Sci 2015;7:S403-8

3 Brenner $\mathrm{M}$, Hearing VJ. Modifying skin pigmentation—approaches through intrinsic biochemistry and exogenous agents. Drug Discov Today Dis Mech 2008;5: e189-99.

Copyright 2016 BMJ Publishing Group. All rights reserved. For permission to reuse any of this content visit http://group.bmj.com/group/rights-licensing/permissions.

BMJ Case Report Fellows may re-use this article for personal use and teaching without any further permission.

Become a Fellow of BMJ Case Reports today and you can:

- Submit as many cases as you like

- Enjoy fast sympathetic peer review and rapid publication of accepted articles

- Access all the published articles

- Re-use any of the published material for personal use and teaching without further permission

For information on Institutional Fellowships contact consortiasales@bmjgroup.com

Visit casereports.bmj.com for more articles like this and to become a Fellow 